\title{
Research on the Path of College Students' Innovation and Entrepreneurship Education
}

\author{
Xiaokui Wang \\ Sichuan University of Arts and Science, Sichuan, China \\ Email:Pl19800710@163.com
}

How to cite this paper: Wang, X. K. (2020). Research on the Path of College Students' Innovation and Entrepreneurship Education. Open Journal of Social Sciences, 8, 298-305.

https://doi.org/10.4236/jss.2020.83027

Received: February 5, 2020

Accepted: March 22, 2020

Published: March 25, 2020

Copyright $\odot 2020$ by author(s) and Scientific Research Publishing Inc. This work is licensed under the Creative Commons Attribution International License (CC BY 4.0).

http://creativecommons.org/licenses/by/4.0/

\begin{abstract}
Innovation and entrepreneurship is the engine of economic and social development and an important way to improve people's livelihood. Innovation and entrepreneurship education can promote the cultivation of innovative talents, the realization of self-worth, economic and social development, and the construction of an innovative country, but there are also unfavorable factors such as insufficient implementation, curriculum construction, and environmental optimization. This article makes practical researches in terms of strengthening the awareness of innovation and entrepreneurship, creating an atmosphere of innovation and entrepreneurship, improving the policy and curriculum of innovation and entrepreneurship, selecting mentors for innovation and entrepreneurship, strengthening the practice of innovation and entrepreneurship, and building platforms for innovation and entrepreneurship.
\end{abstract}

\section{Keywords}

College Students, Innovation, Entrepreneurship, Path Research

\section{Introduction}

The report of the $18^{\text {th }}$ National Congress of the Communist Party of China pointed out that it is necessary to deepen the reform of innovation and entrepreneurship education in colleges and universities, promote the transformation of educational ideals and ideas, reform the training mode of talents, strengthen the practice of students' innovation and entrepreneurship, and cultivate university students' independent thinking, critical thinking, and innovative and pioneering spirit in an attempt to enhance the innovative and entrepreneurial ability of college students (Notice of the Ministry of Education, 2019), and cultivate high-level, application-oriented, composite and innovative talents for the construction of an innovative country. The author once served as the secretary of 
the Youth League Committee of the school and the mentor of innovation and entrepreneurship, directed and packaged more than 10 college student projects, successfully hosted the application for the establishment of the second group of university student innovation and entrepreneurship clubs in Sichuan province. Through continuous research and practice, the writer gradually explored a workable work path, through which the innovation and entrepreneurship education has yielded better results.

\section{Significance of Innovation and Entrepreneurship Education for College Students}

1) Promote the cultivation of innovative talents. The progress of the country, the development of the nation, the revitalization of the countryside, and the happiness of the people all depend on the effective support of talents. International political games, economic contests between major powers, local military conflicts, ethnic cultural conflicts, and modern technological competition, especially the current COVID-19 infection in China, all urgently need intelligent and innovative talents. “Qian Xuesen's Question” shows that China’s current university education lacks the soul of innovation. As the highland for talent training, colleges and universities should strengthen the construction of institutional mechanisms for innovative talent training. The Ministry of Education requires colleges and universities to do a good job in the education of innovation and entrepreneurship for college students, strengthening their quality of innovation, tough will, keen observation, forward thinking, rich knowledge, scientific practice, and vigorously cultivating innovative talents in order to build a well-off society in an all-round way, improve the national governance system and capacity building, achieve the "two hundred years" goal, with intellectual security as talent guarantee.

2) Promote self-worth. College students have a comprehensive knowledge system, strong professional skills, and an active spirit of innovation. They are the most important, autonomous and dynamic entrepreneurial group, and they organically integrate their youth and entrepreneurial spirit into the Chinese dreams. More and more college students are actively participating in the upsurge of innovation and entrepreneurship. 2241 universities participated, 370,000 entries, and more than 1.5 million students participated in China's "Internet+" College Students Innovation and Entrepreneurship Competition. Through practice and exploration, they have achieved breakthroughs and innovations, completed the transition from "creation generation" to "rich generation", demonstrated their talents, and realized their own value in life.

3) Promote economic and social development. The Ministry of Education issued the Opinions on Vigorously Promoting Innovation and Entrepreneurship Education in Colleges and Universities and Independent Entrepreneurship Work for College Students. The document indicates that innovation and entrepreneurship education is a requirement of the current national development 
strategy and social and economic development. The implementation of innovative entrepreneurship education for college students can cultivate their entrepreneurial spirit, consolidate their entrepreneurial awareness, enhance their entrepreneurial level, and promote their entrepreneurial success. In the face of social competition, college students ought to combine their expertise and familiar fields, carry forward the spirit of hard work, give play to innovation and entrepreneurship, and provide scientific and accurate policies to provide jobs for the society, create and accumulate their own wealth, and promote social and economic structure. The optimization has promoted the upgrading of the industry, stimulated the development of the national economy, realized the people's livelihood, and promoted social harmony and stability.

4) Promote the construction of an innovative country. The report of the $19^{\text {th }}$ National Congress of the Communist Party of China proposes that to speed up the construction of an innovative country and create its hard core connotation is the innovation quality of the people. Youth is the future of the country, and college students are the backbone and leading figures among the youth. It is important for colleges and universities to do a good job in innovation and entrepreneurship education. Colleges and universities should deepen education reform, follow the laws of education and teaching, explore the path of talent growth, strengthen the "innovation" element in the talent training model, optimize the curriculum setting, enrich the campus culture, and strive to improve the innovative and entrepreneurial awareness, thinking, knowledge, skills, and physical fitness of college students, fully stimulating their creativity. Scientific and technological innovation is the driving force for the construction of an innovative country. Colleges and universities must fully perform their functions, improve the level of scientific research, encourage the high-level experts and scholars to talk about academic frontiers, guide students carefully, be academic leaders, and achieve academic breakthroughs and leadership. Joint education mechanism should be established among universities, enterprises, industries, and research institutes in order to promote the combination of teaching, scientific research, practice, and innovation to lay a solid foundation for building an innovative country.

\section{Problems of Innovation and Entrepreneurship Education for College Students}

1) Insufficient implementation. First, at the school level, the Ministry of Education has made careful arrangements and effective deployment of innovation and entrepreneurship in colleges and universities. The colleges and universities have also formulated relevant rules and regulations and put forward a series of measures, but they are oftentimes careless and impractical. The cooperation and integration of enterprises, industries and scientific research institutes are not enough, and there is no true integration model of "production, learning, research, and use". The second is at the teacher level. Most teachers simply pass on knowledge, teach and solve puzzles; they do not conduct in-depth research on 
innovation and entrepreneurship, have no practical experience in innovation and entrepreneurship, and have not implanted ideas about innovation and entrepreneurship in the curriculum. They cannot effectively guide and inspire students to be innovative and entrepreneurial. The third is at the student level. Although college students have a certain sense of innovation and entrepreneurship, yet affected by their own knowledge, thinking, skills, funds, and connections, they are not confident in innovation and entrepreneurship; they inevitably hesitate, and fear failure, which necessarily reduces their dynamics for innovation and entrepreneurship.

2) Insufficient curriculum construction. In the selection of teaching materials, the concepts and cases are mostly macroscopic, fail to be refined and used, and are not combined with the professional training plan to reflect professional characteristics. In terms of setting up courses, most of them are conducted in the form of lectures or elective courses. Some elementary entrepreneurship courses are not attractive to students, and they are not targeted, effective and systematic. In the practice of education, they often organize several entrepreneurial design competitions, or organize participation in the Challenge Cup, China College Students' Entrepreneurship Competition, "Internet+" and other events that did not really proceed from reality, strengthen the education and training of innovation and entrepreneurship skills, and provide effective guidance; In terms of teaching management, the professional department had less overall planning. Instead, group organizations participated more, management was scattered, and there was no form of a joint force.

3) Insufficient environmental optimization. Although universities and colleges vigorously carry out innovation and entrepreneurship education, set up a full-time department of innovation and entrepreneurship, improve the construction of the curriculum system, increase the elements of innovation and entrepreneurship in the talent training program, and strengthen the guidance and practice of innovation and entrepreneurship, but in fact, they are not careful and practical. The strong atmosphere of innovation and entrepreneurship has not been effectively formed. In addition, the social environment has certain obstacles to college students' innovation and entrepreneurship activities. Although the state has a policy on college students' innovation and entrepreneurship, there are no specific policies for practical conveniences, such as the financing of innovation and entrepreneurship (Tang \& Wang, 2011).

\section{Research on the Path of College Students' Innovation and Entrepreneurship Education}

1) Strengthen the awareness of innovation and entrepreneurship. General Secretary Xi Jinping pointed out that we must speed up the reform of the education system, focus on cultivating students' innovative consciousness, shape their innovative spirit, and build a team of innovative and entrepreneurial talents (Mao, 2017). Innovation and entrepreneurship is the engine of economic and 
social development, especially technological innovation, and it is also the prerequisite for building an innovative country. College students are elite groups in society. They have high IQ, independent thinking, systematic knowledge, professional skills, good physique and vigorous energy. They are the most important group of innovation and entrepreneurship. It is necessary for us to cultivate innovative thinking, shape innovation quality, enhance entrepreneurial skills, tap entrepreneurial potential, stimulate entrepreneurial interest, and establish the awareness of innovation and entrepreneurship through innovation and entrepreneurship education.

2) Create an atmosphere of innovation and entrepreneurship. A strong atmosphere of innovation and entrepreneurship is a booster for college students innovation and entrepreneurship and a prerequisite for guiding college students to successfully start their own businesses. Through new media platforms such as the official website, Weibo, WeChat, QQ group, and traditional media such as campus radio, blackboard newspapers, display boards, and posters, universities carry out multi-carrier, multi-level innovation and entrepreneurship promotion, and provide information about the real-time national policies and market trends for entrepreneurial college students. They should carefully plan all kinds of innovative academic lectures, carefully set up various innovation and entrepreneurship courses and carry out a large number of innovative entrepreneurship practice activities, thus broadening students' horizons, expanding student awareness and inspiring student to think, and enhancing student capabilities; they should select outstanding and successful entrepreneurial cases to present to students. Successful entrepreneurs should be invited to talk about their own entrepreneurial struggles and visits to successful entrepreneurial enterprises should be organized in order to stimulate university students' innovation and entrepreneurship. They should, in the meantime, fully explore the deeds of innovation and entrepreneurship of college students, establish advanced models, and create a strong atmosphere of innovation and entrepreneurship of "comparing, learning, catching up, and surpassing".

3) Improve policies for innovation and entrepreneurship. Colleges and universities need to establish a set of rules and regulations that encourage college students to innovate and start businesses, such as reforming the teaching system, improving regulations for managing student status, and providing guidance services for entrepreneurship. They should establish a system of accumulating and converting credits for innovative entrepreneurship among independent entrepreneurial college students. Students' participation in competitions, subject research, project experiments, publishing of papers, obtaining patents, and selfemployment can be converted into credits. College students who have the willingness to start a business can enjoy the flexible academic system implemented by universities. The length of study should be relaxed and adjustment of academic progress allowed. Management regulations should be retained such as suspension of schooling, innovation, and entrepreneurship (Full Text of the 
Policy on College Students' Innovation and Entrepreneurship, 2019). Colleges and universities should actively build information service platforms, implement full-process guidance, continuous assistance, and one-stop services. According to the needs of students, they should timely provide national policies and market trends feedback. Local governments should implement tax incentives, business guarantee loans and discounts, waive related administrative fees, and free business services for students.

4) Improve the course of innovation and entrepreneurship. Colleges and universities should fully integrate and tap resources, provide selective courses, compulsory courses, and academic lectures on innovation and entrepreneurship in accordance with the actual situation of students, attach importance to basic education in entrepreneurship, and cultivate students' entrepreneurial awareness and quality; They should focus on the introduction of cutting-edge disciplines and the study of innovative methods, improve students' innovation ability and level, make online open courses such as curtain lessons, video public courses, and implement credit certification and learning certification available. Four-year progressive training should be implemented. In the first academic year, lectures on entrepreneurial theory are taught to cultivate students' awareness of innovation and entrepreneurship. In the second academic year, practice classes on innovation and entrepreneurship ought to be established to cultivate students' practical ability to innovate and start up. In the third academic year should feature in-depth research and development. Practice base innovation and entrepreneurship and other methods to strengthen innovation and entrepreneurship ability training. In the fourth academic year, focus should be laid on practice and innovation and entrepreneurship results-oriented education to cultivate high-level innovative talents (Lei, 2018).

5) Selection of innovative entrepreneurs. Good teachers make good apprentices, and good mentors can train excellent students. A good teaching team is the basic guarantee for talent training in colleges and universities. Highly respected and knowledgeable teachers are selected both inside and outside the school. At the same time, some outstanding management talents, scientific and technological talents and entrepreneurial talents are hired to form a team of highly skilled tutors who are complementary in knowledge, work and teaching (Li, 2017). A mentor management system and evaluation mechanism should be established, paying attention and recognition to mentoring and effective mentors in terms of title evaluation, promotion, and performance rewards. Special funds should be allocated each year for teachers' guidance on innovation and entrepreneurship and training for improving the quality of teaching. Through training in schools, off-campus training, and sending teachers to companies for study, the training and practical training of teachers for innovation and entrepreneurship will be strengthened. It is also beneficial to support innovation and entrepreneurship of schoolteachers, encourage teachers to industrialize scientific and technological achievements in academic achievements, patents, inventions and creations. 
6) Strengthen the practice of innovation and entrepreneurship. In order to stimulate the vitality of college students' innovation and entrepreneurship and lead them to start successful businesses, it is necessary to carry out innovative entrepreneurship education activities. Carrying out a wealth of innovation and entrepreneurship activities can cultivate students' awareness of innovation, stimulate their spirit of innovation, shape their innovative personality, broaden their entrepreneurial horizons, improve entrepreneurial knowledge, enhance entrepreneurial skills, and expand entrepreneurial space so that they can exercise and grow in practice and actual combat. Colleges and universities should actively organize and launch a series of innovation and entrepreneurship activities, such as the "Challenge Cup" college students extracurricular academic scientific and technological works competition, "China's College Students' Entrepreneurship Competition", "Marketing" design competition, "Internet+" innovation and entrepreneurship competition, entrepreneurship salon, innovation entrepreneurship training, innovation and entrepreneurship project docking and other activities. Students should be encouraged to participate in various innovation and entrepreneurship associations, entrepreneurial clubs and other societies, whereby they can strengthen their practical training in entrepreneurship, increase entrepreneurial experience, and enhance entrepreneurial capabilities.

7) Build an innovation and entrepreneurship platform. Colleges and universities should integrate relevant resources on campus, strengthen the construction of grounds and conditions for students' entrepreneurial bases, centralize the establishment of undergraduate entrepreneurial venues, and equip them with necessary entrepreneurial public facilities and equipment to form a certain scale, diversified and distinctive undergraduate entrepreneurship training and entrepreneurship projects incubation base (Yu, 2011). Relying on the University Student Innovation and Entrepreneurship Club, colleges and universities should also provide entrepreneurial policy consultation, entrepreneurship project registration and guidance for college students, selects excellent entrepreneurial projects to enter and incubate, use websites, WeChat and other information platforms to timely promote and promote our university's latest innovation and entrepreneurship activities and achievements. The role of the entrepreneurial mentor team is then to provide face-to-face guidance services for student entrepreneurial projects, actively contact the society, government, and enterprises to carry out all-round cooperation, assists the entrepreneurial team to apply for national preferential policies such as small entrepreneurial loans, recommends outstanding projects, and jointly promote college students to start their own businesses.

\section{Conflicts of Interest}

The author declares no conflicts of interest regarding the publication of this paper.

\section{References}

Full Text of the Policy on College Students' Innovation and Entrepreneurship (2019). http://www.xuexila.com/chuangyee/zhengce/c225972.html 
Lei, G. (2018). Research on Four-Year Progressive Innovation and Entrepreneurship Education in Universities: Taking Sichuan University of Arts and Science as an Example. Continuing Education, 5, 10-12.

Li, S. (2017). Discussion on the Construction of Innovation and Entrepreneurship Mentor Team. Education Modernization, 10, 20-21.

Mao, L. N. (2017). Analysis on the Cultivation of College Students' Innovative and Entrepreneurial Consciousness and Spiritual Molding. Theoretical Research, 6, 16-18.

Notice of the Ministry of Education on Printing and Distributing the "Administrative Measures for the Innovation and Entrepreneurship Training Program of National University Students" (2019).

http://www.moe.gov.cn/srcsite/A08/s5672/201907/t20190724_392132.html

Tang, G. L., \& Wang, Y. B. (2011). Study on the Cultivating Path of College Students' Innovation and Entrepreneurial Ability. Journal of Sichuan University of Science \& Engineering (Social Sciences Edition). 26, 76-79.

Yu, G. Y. (2011). Approaches to the Construction of Entrepreneurship Bases for Local College Students. The Party Building and Ideological Education in Schools, 6, 76-77. 